\title{
21. Living Standards in Sydney and Japanese Cities: A Comparison ${ }^{1}$
}

\author{
Ian Castles ${ }^{2}$
}

In the Report on the Economy (the Economic White Paper) for the fiscal year 1988, the Economic Planning Agency of the Japanese Government devoted a chapter to 'Issues for Enriching Livelihood of the People'. ${ }^{3}$ After noting that Japan's per capita income was the world's highest and that 'In the broad view, it can be said that Japan has achieved affluence', the Report went on:

However, the people's view diverges somewhat. Even when we account for the people's desire for improvement by always seeking something better, conditions have not reached a state where the people are satisfied and have a sense of adequacy.

The foreword to the same Report by the minister responsible for the Agency included the comment that, although Japan was an affluent country

It cannot be denied...that in our day-to-day living we cannot get the full feeling of the affluence. Much needs to be improved in such areas of daily living as food, housing and working hours.

In Australia's case, much concern has been expressed in recent years that, over the longer term, average living standards have fallen in relation to those in other countries. For example, the following comments were made by three different eminent observers at a symposium in 1984:

...Australia has slipped down the international league table of income per head, from equal first a century ago to a position below most of Western Europe and Japan now.

Why then does Australia, once at the top in living standards, now rank only sixteenth?

Australia will have to struggle to recapture that degree of relative affluence that it enjoyed up to the final quarter of the nineteenth century. ${ }^{4}$

\footnotetext{
1 First published in October 1990 as a mimeograph by the Australian Bureau of Statistics. Later published as a chapter in Kyoko Sheridan (ed), 1992, The Australian Economy in the Japanese Mirror, University of Queensland Press. Except where otherwise indicated, all figures and tables in this chapter are Castles' own.

2 Australian Statistician, Canberra, October 1990.

3 Japan, Economic Planning Agency, Report on the Economy FY (1988). Toyko: 179.

4 Australia: the Daedalus Symposium, Sydney, (1985). The comments are made in essays by Hugh Stretton (199), Gordon Jackson (255) and Bruce Williams (291).
} 
The comparisons which provide the basis for these comments, and those in the Japanese Economic Planning Agency report, are national accounting estimates of real per capita expenditure or product. These estimates are subject to important limitations when used as indicators of living standards, because they are essentially concerned with market transactions.

This paper compares the living standards and modes of living in four Japanese prefectures with those in Sydney. The comparisons are based largely, although not entirely, on statistics compiled by the Statistics Bureau, Management and Co-ordination Agency, Japan and by the Australian Bureau of Statistics (ABS). ${ }^{5}$ Although the comparisons are restricted to specific geographical areas within the two countries, they are not confined to those aspects of living standards which are measured in the national accounts. They therefore provide a more comprehensive basis for the assessment of relative living standards than the conventional national accounting framework.

\section{The Japanese cities and Sydney}

The four Japanese prefectures chosen for the comparison are Tokyo-to, Kanagawa-ken, Kyoto-fu and Osaka-fu. ${ }^{6}$ They had a combined population in 1988 of 31 million, or just over one-quarter of the total population of Japan.

The prefecture of Tokyo-to has a population of almost 12 million of which over $70 \%$ live in the city (ku-area) of Tokyo. The daytime population of the ku-area is even greater, because of the large numbers of workers who commute to the city from the remainder of the prefecture and the adjoining prefectures.

One of these is Kanagawa-ken, which has a population of almost eight million. Most people in Kanagawa live in the cities of Yokohama and Kawasaki.

Kyoto-fu has a population of more than 2.5 million, most of whom reside in the city (shi) of Kyoto.

Osaka-fu has a population of over 8.5 million, of which about 30 per cent live in Osaka-shi and most of the remainder in densely populated neighbouring areas.

Sydney is Australia's largest city, and the capital of the most populous state, New South Wales. In 1988, the Sydney Statistical Division, which extends beyond the urban area, had a population of 3.6 million. This was over 60 per cent of the

5 The range of collections and the depth of detail in the publication of results by the Japanese Statistics Bureau are most impressive. Japan is perhaps the only country whose published statistics alone would provide support for comparisons at the level of detail attempted in this paper.

6 The suffixes will generally be omitted except where they are necessary to distinguish the prefectures from the cities with the same name. 
population of New South Wales and more than 20 per cent of Australia's total population. Although there are some important differences, the standard and modes of living of people in Sydney can be regarded as broadly representative of those in Australia's major urban centres.

\section{Comparisons of population density}

One important pointer to an understanding of the vast difference in modes of living between the Japanese cities and Sydney is the fact that, in relation to population, Sydney occupies a far greater area. Details of area, population and population density are summarised in Table 1.

An examination of that Table 1 shows that:

- Although the area of the Sydney Statistical Division is greater than the combined area of the four Japanese prefectures, the population in the division at the 1986 Australian census was only about one-tenth of the population in these prefectures at the 1985 census of Japan.

- The population of the ku-area of Tokyo was almost six times as great as that of a group of contiguous inner Sydney statistical subdivisions with a combined area only slightly smaller than that of the ku-area of Tokyo.

- The population of a group of contiguous districts within Osaka-shi was almost five times as great as that of Sydney's most densely populated statistical subdivision (Eastern suburbs), which has an area almost as great as these districts of Osaka.

The far greater area of land space per capita in Sydney, by comparison with the Japanese cities, is both the outcome of different modes of living in the past and the cause of different modes of living in the present. The differences extend to almost all aspects of the way people live - in their homes and workplaces, and how they travel from one to the other; in shops and public buildings, and their immediate environs; and in private and public recreational spaces and the ways in which they are used. 
Measuring and Promoting Wellbeing: How Important is Economic Growth?

Table 1 Sydney and four Japanese prefectures: area, population and density of population

\begin{tabular}{|c|c|c|c|c|}
\hline & Area sq km & $\begin{array}{l}\text { Population } \\
\text { ('000) }\end{array}$ & $\%$ of Population & $\begin{array}{l}\text { Population } \\
\text { per sq km }\end{array}$ \\
\hline \multicolumn{5}{|c|}{ Sydney statistical division } \\
\hline Inner Sydney & 73.04 & 258.5 & 7.7 & 3,540 \\
\hline Eastern Suburbs & 58.09 & 226.5 & 6.7 & 3,900 \\
\hline $\begin{array}{l}\text { Canterbury- } \\
\text { Bankstown }\end{array}$ & 109.99 & 280.1 & 8.3 & 2,546 \\
\hline Inner West & 49.48 & 148.6 & 4.4 & 3,004 \\
\hline Central Western & 133.29 & 256.2 & 7.6 & 1,922 \\
\hline Lower Northern & 98.60 & 258.2 & 7.7 & 2,619 \\
\hline $\begin{array}{l}\text { Total selected } \\
\text { statistical } \\
\text { subdivisions }\end{array}$ & 522.49 & $1,428.2$ & 42.4 & 2,733 \\
\hline $\begin{array}{l}\text { Total statistical } \\
\text { division }\end{array}$ & $12,154.30$ & $3,364.9$ & 100.0 & 277 \\
\hline \multicolumn{5}{|c|}{ Tokyo-to } \\
\hline Selected Districts & 420.92 & $6,473.1$ & 54.7 & 15,378 \\
\hline Total Ku-area & 597.89 & $8,354.6$ & 70.6 & 13,973 \\
\hline Total Tokyo-to & $2,162.34$ & $11,829.4$ & 100.0 & 5,471 \\
\hline \multicolumn{5}{|c|}{ Kanagawa-Ken } \\
\hline Yokohama-shi & 430.75 & $2,992.9$ & 40.3 & 6,948 \\
\hline Kawasaki-shi & 136.47 & $1,088.6$ & 14.6 & 7,977 \\
\hline $\begin{array}{l}\text { Total Kanagawa- } \\
\text { ken }\end{array}$ & $2,402.07$ & $7,432.0$ & 100.0 & 3,094 \\
\hline \multicolumn{5}{|c|}{ Kyoto-fu } \\
\hline Kyoto-shi & 610.61 & $1,479.2$ & 57.2 & 2,423 \\
\hline Total Kyoto-fu & $4,612.90$ & $2,586.6$ & 100.0 & 561 \\
\hline \multicolumn{5}{|c|}{ Osaka-fu } \\
\hline Selected districts & 59.65 & $1,081.9$ & 12.5 & 18,138 \\
\hline Total Osaka-shi & 213.08 & 2.636 .2 & 30.4 & 12,372 \\
\hline Total Osaka-fu & $1,867.86$ & $8,668.1$ & 100.0 & 4,641 \\
\hline
\end{tabular}

Source: The table shows the 1986 Census populations of Sydney statistical division and of six contiguous statistical subdivisions within the division; and the 1985 Census populations of the four Japanese prefectures, five cities within the ku-area of Tokyo and within Osaka-shi.The selected districts of Tokyo are those numbered 104-120 in Population of Tokyo-to, 1985 Population Census of Japan, Abridged Report Series No. 2, and the selected districts of Osaka are those numbered 115-122 in Population of Osaka-fu in the same series.

These differences are not readily captured in statistics. One revealing indication is from household expenditure survey results, which show that in 1988 the spending on rents for car parking by households in Tokyo-to and Osaka-shi was considerably greater than their expenditures on petrol. In Sydney, by contrast, household spending on petrol in 1988-89 exceeded that on parking fees by 
a margin of more than 40 to 1 . These comparisons demonstrate the extent to which expenditure patterns can be influenced by the availability and cost of space. They also highlight the limitations of inter-country comparisons of living standards which rely on the conversion of expenditures into a common currency.

\section{Comparisons of the use of time}

Another pointer to an understanding of the differences between Sydney and the Japanese cities is in the differing ways in which people use their time.

Statistical information on this subject is available from the Survey of Time Use and Leisure Activities ${ }^{7}$ in Japan in 1986 (following similar surveys in 1976 and 1981) and from the Time Use Pilot Survey ${ }^{8}$ conducted by the ABS in Sydney in May-June 1987. Although the relative size of the sample in the Sydney survey was much smaller than in the Japanese prefectures, it was large enough to give a broad indication of the patterns of time use between major types of activities.

The differences in the pattern of time use between Sydney and the Japanese centres are exhibited in Table 2.

Table 2 Sydney and four Japanese prefectures: use of time by all persons aged 15 years and over

\begin{tabular}{|c|c|c|c|c|c|}
\hline & Sydney & Tokyo & Kanagawa & Kyoto & Osaka \\
\hline \multicolumn{6}{|c|}{ Hours per week } \\
\hline Primary activities & 75.4 & 73.4 & 72.1 & 73.1 & 72.7 \\
\hline Sleep & 59.9 & 54.2 & 53.3 & 54.5 & 53.9 \\
\hline Personal care & 4.9 & 7.2 & 7.4 & 7.2 & 7.2 \\
\hline Meals & 10.6 & 12.0 & 11.4 & 11.4 & 11.6 \\
\hline Labour force work & 21.1 & 29.8 & 28.4 & 30.9 & 30.7 \\
\hline Education & 3.6 & 4.2 & 4.1 & 4.7 & 4.2 \\
\hline Commuting & 4.0 & 5.0 & 6.1 & 4.0 & 4.9 \\
\hline Housework & 18.3 & 14.8 & 16.5 & 15.6 & 15.6 \\
\hline Housekeeping & 11.9 & 10.6 & 11.9 & 11.5 & 11.3 \\
\hline Childcare & 3.3 & 1.4 & 1.7 & 1.6 & 1.6 \\
\hline Shopping & 3.1 & 2.8 & 2.9 & 2.5 & 2.7 \\
\hline Tertiary activities & 45.6 & 40.8 & 40.8 & 39.7 & 39.9 \\
\hline Total & 168.0 & 168.0 & 168.0 & 168.0 & 168.0 \\
\hline
\end{tabular}

7 Japan, Statistics Bureau, Management and Co-ordination Agency. The Survey on Time and Use and Leisure Activities 1986.

8 Australian Bureau of Statistics, Information Paper: Time Use Pilot Survey (ABS Catalogue 4111.1). 
The classification of activities used in Table 2 is based primarily upon that used in the Japanese Survey, which is explained by the Statistics Bureau in the following terms:

Activities are grouped into 3 broad areas, called 'primary activities', 'secondary activities', and 'tertiary activities'. Primary activities refer to those which are physiologically necessary, and consists of 'sleep', 'meals' and 'personal care'. Secondary activities comprise those which each person is committed to perform as a member of a family or of the society. Included are 'work (for pay or profit)', 'studies and researches (in connection with academic education)', 'commuting to work or school', 'housekeeping', 'child care', and 'shopping'. These activities may be regarded as socially obligatory activities. From another point of view, they represent production activities in a broad sense. Tertiary activities include all other activities such as 'hobbies and amusements', 'sports', etc. Time spent in tertiary activities corresponds to what is usually called 'free time'. ${ }^{9}$

There are three aspects of this classification which need some explanation. Firstly, the boundary between primary and tertiary activities is not always clear-cut. Although it is physiologically necessary that a certain amount of time be devoted to activities such as sleeping and eating, it is not the case that all of the time which people devote to these activities is physiologically necessary. On the contrary, much of the time spent on a leisurely meal, for example, could be regarded as 'free time'.

Secondly, the boundary between secondary and tertiary activities is also not clear-cut. It can be argued, for example, that gardening and home maintenance activities are unpaid household work rather than 'free time' activities. In the Japanese time use survey, however, 'gardening' and 'do it yourself carpenter' are explicitly identified as falling within the 'hobbies and amusements' classification of activities.

Thirdly, some of the apparent differences between Sydney and the Japanese prefectures may arise from variations in the particular form of the questions asked and the guidance given to respondents. For example, the greater number of hours apparently allocated to child care in Sydney may reflect the fact that, in the Sydney survey, 'child care/minding', included any activity 'where it is necessary for the respondent to remain in the vicinity of the child but not necessarily to interact with him/her (e.g. where a child is sleeping or playing in another room while the respondent performs other activities elsewhere) ${ }^{\prime}{ }^{10}$

9 The Survey on Time Use..., Whole Japan, Time Spent on Activities (1): 18.

10 ABS, Time Use Pilot Survey (ABS Catalogue No. 4111.1): 75. 
These qualifications having been made, it is obvious from Table 2 that there is a striking difference between Australia and Japan in the amount of time devoted to 'labour force work'. This was higher in the Japanese prefectures than in Sydney by proportions ranging from 35 per cent (Kanagawa) to 46 per cent (Kyoto).

It must be emphasised that the table shows the average weekly hours devoted to various activities by all persons aged 15 and over. Thus the average number of hours allocated to labour force work and to commuting by employed persons was much greater than the average for all persons which is shown in the table. Conversely, people who were not in the paid labour force devoted much more time, on average, to housework and tertiary activities.

Another aspect of the comparison deserves special mention. The proportion of children in the total population is significantly higher in Sydney than in the Japanese prefectures. In 1988, the proportion of the population aged under 15 years was 21.4 per cent in Sydney, compared with less than 19 per cent in Kanagawa, Kyoto and Osaka and 16.1 per cent in Tokyo. This means that the difference between Sydney and the Japanese prefectures in the amount of labour force work per head of the total population is even greater than shown in Table 2. Applying the 1988 population figures to the 1986 and 1987 time use survey results, the indicated average hours of labour force work per head of the total population (the concept which would be most appropriate in the context of the international comparisons of per capita incomes) was greater than in Sydney by 39 per cent in Kanagawa and by 50 per cent or more in Tokyo, Kyoto and Osaka.

The detailed time use survey results show that the large difference between the two countries in the time devoted to labour force work has several components.

First, the working day in Japan is, on average, considerably longer. This is illustrated in Table 3 which shows, for Sydney and the four Japanese prefectures, the proportion of the population at work at specified hours on a weekday. The table shows that at 8am the proportion of people already at work was somewhat greater in Sydney than in the Japanese prefectures. By 10am, however, the proportion of the adult population at work was higher in the Japanese centres by seven to ten percentage points. By $4 \mathrm{pm}$ this difference had widened to between 17 and 21 percentage points, and at $6 \mathrm{pm}$ and $8 \mathrm{pm}$ the proportion of persons who were working was around twice as great as in Sydney.

A second component of the difference in working hours was the far greater amount of labour force work which was undertaken in Japan at weekends. Taking an average of all males over 15 years of age, whether working or not, the time spent at work on Saturday in the Japanese prefectures ranged from less than five hours in Kanagawa to almost six hours in Osaka. These working hours on Saturday are comparable with average hours in Sydney on a weekday. 
Measuring and Promoting Wellbeing: How Important is Economic Growth?

Table 3 Sydney and four Japanese prefectures: labour force work on weekdays

\begin{tabular}{|l|c|c|c|c|c|}
\hline & Sydney & Tokyo & Kanagawa & Kyoto & Osaka \\
\hline \multicolumn{7}{|c|}{ Percentage engaged in labour force work } \\
\hline Morning \\
\hline $10 \mathrm{am}$ & 21.9 & 15.2 & 16.6 & 19.3 & 20.4 \\
\hline \multicolumn{7}{|c|}{ Afternoon } \\
\hline $2 \mathrm{pm}$ & 40.4 & 49.3 & 47.1 & 49.8 & 50.6 \\
\hline $4 \mathrm{pm}$ & 39.6 & 50.1 & 48.0 & 50.7 & 50.6 \\
\hline \multicolumn{7}{|c|}{ Evening } \\
\hline $6 \mathrm{pm}$ & 29.4 & 48.6 & 46.7 & 50.5 & 48.8 \\
\hline $8 \mathrm{pm}$ & 9.8 & 24.9 & 21.5 & 25.1 & 23.3 \\
\hline
\end{tabular}

Source: The table shows proportion of persons over 15 years of age engaged in labour force work at the specified hours on weekdays.

For the weekend as a whole, males worked an average of 7-8 hours in the Japanese prefectures, compared with 2 hours 20 minutes in Sydney; and females worked an average of 3-4 hours in the Japanese prefectures, compared with only one hour in Sydney.

Finally, the working life in Japan is much longer, with far more labour force work being done by people over 60 years of age. This is brought out in some detail in Tables 4 and 5 which show, for males and females respectively, the average hours devoted to each of the main activities in each of five age groups.

Table 4 shows, for example, that males aged 60-64 years worked an average of only about 16 hours in Sydney, compared with 30 hours in Kanagawa, 32 hours in Osaka, 35 hours in Tokyo and 41 hours in Kyoto. On average, males aged 65 and over worked less than one hour per week in Sydney, compared with 12 hours in Kanagawa, 16 hours in Osaka, 17 hours in Tokyo and 21 hours in Kyoto. In relative terms, the differences between Sydney and the Japanese prefectures in the amount of labour force work done by older women was even greater.

Taking men and women together, and using the average hours worked in the 4059 years age group in each city-prefecture as the 'normal' for adult workers, the estimates of hours worked in the 60-64 years and 65 years and over age groups imply the equivalent of a standard retirement age of around 62 years in Sydney, compared with 66 years in Kanagawa and Osaka, 67 years in Tokyo and 69 years in Kyoto.

A comparison of Tables 4 and 5 reveals other important differences in modes of living between Sydney and the Japanese centres. It shows, for example, that 
whilst housework (including child care and shopping) occupied far more of women's time than of men's in Sydney, the difference between the sexes was very much greater in the Japanese prefectures.

Table 4 Sydney and four Japanese prefectures: use of time by males

\begin{tabular}{|c|c|c|c|c|c|}
\hline & Sydney & Tokyo & Kanagawa & Kyoto & Osaka \\
\hline \multicolumn{6}{|c|}{ Average hours per week of all males in age group } \\
\hline \multicolumn{6}{|c|}{ Primary activities } \\
\hline $15-24$ yrs & 76.1 & 71.1 & 69.4 & 70.0 & 70.1 \\
\hline $25-39$ & 72.2 & 69.6 & 68.9 & 70.8 & 69.9 \\
\hline $40-59$ yrs & 73.9 & 72.6 & 70.9 & 71.5 & 71.9 \\
\hline $60-64$ yrs & 75.0 & 76.2 & 77.0 & 75.9 & 75.1 \\
\hline 65 yrs \& over & 83.0 & 84.2 & 83.8 & 82.7 & 80.8 \\
\hline \multicolumn{6}{|c|}{ Labour force work } \\
\hline $15-24$ yrs & 24.0 & 21.5 & 24.1 & 19.0 & 24.2 \\
\hline $25-39$ yrs & 36.9 & 53.7 & 51.8 & 53.6 & 53.2 \\
\hline $40-59$ yrs & 35.8 & 51.3 & 49.4 & 53.5 & 52.2 \\
\hline $60-64$ yrs & 16.3 & 35.4 & 29.9 & 41.2 & 32.5 \\
\hline 65 yrs \& over & 0.9 & 17.0 & 11.8 & 21.2 & 16.3 \\
\hline \multicolumn{6}{|c|}{ Education } \\
\hline $15-24$ yrs & 16.4 & 19.9 & 19.8 & 26.4 & 21.8 \\
\hline \multicolumn{6}{|c|}{ Commuting } \\
\hline $15-24$ yrs & 6.3 & 7.8 & 9.0 & 6.4 & 8.0 \\
\hline $25-39$ yrs & 5.8 & 7.8 & 9.4 & 5.6 & 7.6 \\
\hline $40-59$ yrs & 5.5 & 6.9 & 9.5 & 6.0 & 6.9 \\
\hline $60-64$ yrs & 3.3 & 4.3 & 4.9 & 4.9 & 4.0 \\
\hline 65 yrs \& over & 0.2 & 1.7 & 1.5 & 1.7 & 1.6 \\
\hline \multicolumn{6}{|c|}{ Housework } \\
\hline $15-24$ yrs & 4.2 & 1.3 & 1.4 & 0.8 & 1.0 \\
\hline $25-39$ yrs & 10.3 & 1.9 & 2.3 & 1.8 & 1.9 \\
\hline $40-59$ yrs & 8.7 & 1.6 & 1.8 & 1.7 & 1.5 \\
\hline 65 yrs \& over & 13.8 & 5.2 & 5.9 & 4.0 & 3.6 \\
\hline \multicolumn{6}{|c|}{ Tertiary activities } \\
\hline $15-24$ yrs & 41.0 & 46.4 & 44.3 & 45.4 & 42.9 \\
\hline $25-39$ yrs & 42.8 & 35.0 & 35.6 & 36.2 & 35.4 \\
\hline $40-59$ yrs & 44.1 & 35.6 & 36.4 & 35.3 & 35.5 \\
\hline $60-64$ yrs & 61.3 & 49.9 & 50.4 & 43.4 & 52.7 \\
\hline 65 yrs \& over & 70.1 & 59.9 & 65.0 & 58.4 & 65.7 \\
\hline
\end{tabular}


Measuring and Promoting Wellbeing: How Important is Economic Growth?

Table 5 Sydney and four Japanese prefectures: use of time by females

\begin{tabular}{|c|c|c|c|c|c|}
\hline & Sydney & Tokyo & Kanagawa & Kyoto & Osaka \\
\hline \multicolumn{6}{|c|}{ Average hours per week of all females in age group } \\
\hline \multicolumn{6}{|c|}{ Primary activities } \\
\hline $15-24$ yrs & 77.4 & 74.3 & 72.5 & 72.4 & 73.4 \\
\hline $25-39$ years & 73.4 & 72.5 & 70.5 & 71.1 & 72.2 \\
\hline $40-59$ yrs & 75.0 & 71.8 & 70.5 & 71.1 & 71.5 \\
\hline $60-64$ yrs & 76.7 & 76.5 & 77.7 & 75.1 & 74.6 \\
\hline 65 yrs \& over & 81.1 & 82.6 & 83.8 & 84.5 & 83.3 \\
\hline \multicolumn{6}{|c|}{ Labour force work } \\
\hline $15-24$ yrs & 18.2 & 20.6 & 18.7 & 20.8 & 20.9 \\
\hline $25-39$ yrs & 17.9 & 20.4 & 15.6 & 20.5 & 19.5 \\
\hline $40-59$ yrs & 14.9 & 22.4 & 20.5 & 28.1 & 24.6 \\
\hline $60-64$ yrs & 3.0 & 11.3 & 10.2 & 14.9 & 15.2 \\
\hline 65 yrs \& over & 0.2 & 5.7 & 4.1 & 9.3 & 3.4 \\
\hline \multicolumn{6}{|c|}{ Education } \\
\hline $15-24$ yrs & 14.6 & 16.2 & 18.0 & 19.6 & 17.7 \\
\hline \multicolumn{6}{|l|}{ Commuting } \\
\hline $15-24$ yrs & 6.1 & 8.1 & 9.6 & 6.9 & 7.5 \\
\hline $25-39$ yrs & 2.5 & 3.1 & 2.6 & 2.3 & 2.4 \\
\hline $40-59$ yrs & 2.5 & 2.2 & 2.5 & 1.8 & 2.4 \\
\hline $60-64$ yrs & 0.9 & 1.0 & 0.9 & 0.7 & 0.8 \\
\hline 65 yrs \& overs & 0.0 & 0.6 & 0.5 & 0.5 & 0.2 \\
\hline \multicolumn{6}{|c|}{ Housework } \\
\hline $15-24$ yrs & 13.0 & 7.4 & 7.3 & 7.2 & 8.2 \\
\hline $25-39$ yrs & 35.0 & 36.1 & 43.1 & 39.6 & 39.3 \\
\hline $40-59$ yrs & 31.7 & 34.0 & 36.4 & 33.6 & 34.4 \\
\hline $60-64$ yrs & 32.3 & 32.6 & 34.0 & 31.6 & 30.0 \\
\hline 65 yrs \& overs & 26.7 & 22.9 & 23.5 & 22.5 & 22.2 \\
\hline \multicolumn{6}{|c|}{ Tertiary activities } \\
\hline $15-24$ yrs & 38.7 & 41.4 & 41.9 & 41.1 & 40.3 \\
\hline $25-39$ yrs & 39.2 & 35.9 & 36.2 & 34.5 & 34.6 \\
\hline $40-59$ yrs & 43.9 & 37.6 & 38.1 & 33.4 & 35.1 \\
\hline $60-64$ yrs & 55.1 & 46.6 & 45.2 & 45.7 & 47.4 \\
\hline 65 yrs \& over & 60.0 & 56.2 & 56.1 & 51.2 & 58.9 \\
\hline
\end{tabular}

Thus, in the 25-39 years age group housework occupied an average of 35 hours per week for Sydney women and 10 hours per week for Sydney men. In Kanagawa prefecture, the corresponding averages in this age group were 43 hours for women and two hours for men: by comparison with Sydney, housework occupied eight hours per week more of the time of women and eight hours per week less of the time of men.

A final aspect of the results of the time use survey which deserves some discussion concerns the time which people spend in commuting to and from work or places 
of study. The estimates in Table 2 reveal that the average commuting time for all persons over 15 years is about four hours per week in Sydney and Kyoto, five hours per week in Tokyo and Osaka and over six hours per week in Kanagawa. Average commuting times in the Japanese prefectures would be greater but for the fact that large numbers of workers do not commute at all. At the 1985 Census, the proportion of employed persons who worked at home was 21.9 per cent in Kyoto, 15.7 per cent in Tokyo, 13.3 per cent in Osaka and 11.2 per cent in Kanagawa. ${ }^{11}$ The corresponding proportion in Sydney at the 1986 Census was only 3.3 per cent.

The results of the time use surveys in the two countries, as reported in Tables 2-5, provide a framework for the examination of the relative roles of market and non-market activities.

If the time spent on labour force work is taken as the measure of market activities, and the total time spent on housework and on tertiary activities as the measure of non-market activities, the balance between the two in Sydney and in the four Japanese prefectures can be derived from Table 2 .

On this basis, non-market activities absorbed over three times as much time as market activities in Sydney. The corresponding ratio in the Japanese prefectures was 1.8 times in Kyoto and Osaka, 1.9 times in Tokyo and 2.0 times in Kanagawa.

An examination of estimates for age groups in Tables 4 and 5 reveals even more striking differences between Sydney and the Japanese prefectures in this respect. For example, the average ratio of time spent on non-market activities (as defined) to time spent on labour force work by men in Tokyo rises across the lifecycle from around 0.7 in the 25-39 years age group to about 1.5 in the 60-64 age group. By way of contrast, the corresponding ratio for Sydney men is about 1.5 for the 25-39 and 40-59 age groups, rising to 4.5 for the 60-64 years age group.

In sum, the importance of non-market activities, as indicated by the relative allocation of time, is far greater in Sydney than in the Japanese prefectures selected for this study.

\section{Comparisons of command over goods and services}

For most people, labour force work is seen primarily as an exchange of time for money. It is done not for its own sake but in order to provide the resources for other aspects of living, including for the purchase of the 'necessities of life'.

The next stage in our comparative assessment of living standards will therefore be to examine how much of the working time of employees is needed in order

11 Japan, Statistics Bureau, Major Aspects of Population of Japan, Tokyo, 1986: 160. 
to provide the resources required to purchase necessary supplies of certain foodstuffs and electricity. Unlike most other items of household expenditure, the purchase of these items cannot be deferred, or avoided by the purchase of a cheaper alternative: all households must buy, and regularly pay for, certain basic foodstuffs and electric power (at least for lighting and refrigeration).

Estimates of the levels of weekly and hourly earnings in Sydney and in each of the prefectures are given in Table 6 .

Table 6 Sydney and four Japanese prefectures: employees, average weekly hours worked and average weekly and hourly earnings 1987

\begin{tabular}{|c|c|c|c|c|c|}
\hline & Sydney & Tokyo & Kanagawa & Kyoto & Osaka \\
\hline \multicolumn{6}{|c|}{ Average weekly hours worked } \\
\hline Females & 29.9 & 41.4 & 40.1 & 41.6 & 41.4 \\
\hline Persons & 34.8 & 47.4 & 47.0 & 47.1 & 47.5 \\
\hline Males & 453.5 & 88,490 & 88,510 & 78,490 & 78,830 \\
\hline \multicolumn{6}{|c|}{ Average weekly earnings } \\
\hline & $\$ A$ & Yen & Yen & Yen & Yen \\
\hline Males & 38.5 & 50.8 & 50.4 & 50.3 & 50.7 \\
\hline Females & 308.3 & 41,490 & 36,390 & 35,080 & 34,800 \\
\hline Persons & 392.2 & 71,670 & 71,420 & 62,470 & 63,560 \\
\hline \multicolumn{6}{|c|}{ Average hourly earnings } \\
\hline & $\$ A$ & Yen & Yen & Yen & Yen \\
\hline Males & 11.80 & 1,743 & 1,756 & 1,560 & 1,554 \\
\hline Females & 10.31 & 1,003 & 907 & 894 & 841 \\
\hline Persons & 11.26 & 1,512 & 1,519 & 1,326 & 1,339 \\
\hline & $\%$ & $\%$ & $\%$ & $\%$ & $\%$ \\
\hline \multicolumn{6}{|c|}{ Females as $\%$ of total } \\
\hline Employees & 42.3 & 35.8 & 32.8 & 36.9 & 34.7 \\
\hline Hours worked & 36.3 & 31.2 & 28.0 & 32.6 & 30.2 \\
\hline Total earnings & 33.2 & 20.7 & 16.7 & 20.7 & 19.0 \\
\hline \multicolumn{6}{|c|}{ Female earnings as $\%$ of male } \\
\hline Weekly & 68.0 & 46.9 & 41.1 & 44.7 & 44.1 \\
\hline Hourly & 87.4 & 57.6 & 51.7 & 54.0 & 54.1 \\
\hline
\end{tabular}

Source: The estimates for the Japanese prefectures are derived from Statistics Bureau, Survey of Employment Status 1987, and those for Sydney are derived from unpublished results from the ABS labour force survey for August 1987 and from the survey of Weekly Earnings and Employees, August 1987 (ABS Catalogue no. 6310.0). The estimates of average weekly earnings for both Japan and Australia implied by these surveys are 5-10 per cent lower than the OECD, National Accounts, Detailed Tables, Volume II, 1976-88 by covering estimated wages and salaries (Table 8 ) to a weekly basis and dividing by the number of employees (Table 15). It is usual for estimates of average earnings from household surveys to be somewhat understated.

The estimates are given separately for males and females, and show that average female earnings were a much higher proportion of average male earnings in 
Sydney than in the Japanese cities. On an hourly basis, the ratio was 87 per cent in Sydney, 58 per cent in Tokyo, 54 per cent in Osaka and Kyoto and 52 per cent in Kanagawa.

Taking the average hourly earnings of all employees as the measure of the average value of working time, Tables 7 and 8 provide comparisons of the 'cost' of necessities in terms of working time for Sydney, Tokyo and Osaka.

Table 7A Average annual consumption of selected foods by a family of four in Sydney, and costs of purchase expressed in hours of work in Sydney, Tokyo and Osaka 1987

\begin{tabular}{|c|c|c|c|c|}
\hline & \multirow{2}{*}{$\begin{array}{l}\text { Quantity } \\
\text { consumed in } \\
\text { Sydney }\end{array}$} & \multicolumn{3}{|c|}{ Cost of purchase in hours of work } \\
\hline & & Sydney & Tokyo & Osaka \\
\hline & kg & hours & hours & hours \\
\hline \multicolumn{5}{|c|}{ Cereals } \\
\hline Bread & 121.5 & 17.91 & 29.76 & 38.11 \\
\hline Flour & 3.3 & 0.29 & 0.45 & 0.50 \\
\hline Pasta & 33.2 & 6.43 & 10.49 & 11.90 \\
\hline Rice & 36.1 & 3.59 & 11.50 & 13.45 \\
\hline Biscuits & 21.1 & 9.29 & 12.78 & 14.81 \\
\hline & & 37.51 & 64.98 & 78.77 \\
\hline \multicolumn{5}{|c|}{ Meat and Fish } \\
\hline Beef (a) & 77.7 & 35.40 & 185.22 & 205.60 \\
\hline Pork & 9.6 & 3.88 & 8.97 & 12.02 \\
\hline Ham and bacon & 9.6 & 5.60 & 13.76 & 16.01 \\
\hline Chicken & 28.8 & 8.88 & 18.60 & 23.64 \\
\hline Sausages & 16.1 & 3.79 & 16.41 & 17.05 \\
\hline $\begin{array}{l}\text { Delicatessen } \\
\text { meat }\end{array}$ & 7.3 & 3.89 & 14.08 & 15.70 \\
\hline Fish & 11.3 & 7.30 & 14.27 & 16.65 \\
\hline & & 68.74 & 271.31 & 306.67 \\
\hline \multicolumn{5}{|c|}{ Dairy products and eggs } \\
\hline Fresh milk (litres) & 437.3 & 32.23 & 57.58 & 74.78 \\
\hline Butter & 6.6 & 2.11 & 6.95 & 8.02 \\
\hline Cheese & 20.4 & 11.23 & 17.51 & 20.05 \\
\hline Icecream (litres) & 35.7 & 4.06 & 15.18 & 16.85 \\
\hline Eggs & 20.8 & 5.26 & 3.80 & 4.38 \\
\hline & & 54.89 & 101.02 & 124.08 \\
\hline \multicolumn{5}{|c|}{ Fruit and vegetables } \\
\hline Oranges & 64.5 & 7.90 & 20.89 & 27.26 \\
\hline Lemons & 3.4 & 0.29 & 0.55 & 0.61 \\
\hline Apples & 89.1 & 18.52 & 25.81 & 31.47 \\
\hline
\end{tabular}




\begin{tabular}{|l|c|c|c|c|}
\hline \multirow{2}{*}{} & \multirow{2}{*}{$\begin{array}{c}\text { Quantity } \\
\text { consumed in } \\
\text { Sydney }\end{array}$} & \multicolumn{3}{|c|}{ Cost of purchase in hours of work } \\
\cline { 3 - 5 } & $\mathbf{k g}$ & Sydney & Tokyo & Osaka \\
\cline { 3 - 5 } & 17.5 & hours & hours & hours \\
\hline Bananas & 9.1 & 1.88 & 2.64 & 2.98 \\
\hline Canned fruit & 132.9 & 1.30 & 3.02 & 3.92 \\
\hline Potatoes & 10.6 & 8.50 & 20.12 & 24.71 \\
\hline Onions & 20.4 & 0.94 & 1.00 & 1.15 \\
\hline Carrots & 25.2 & 2.07 & 4.93 & 5.62 \\
\hline Tomatoes & 32.1 & 4.36 & 8.31 & 11.95 \\
\hline Cabbage & & 1.60 & 4.78 & 5.61 \\
\hline & & 47.36 & 92.05 & 115.28 \\
\hline & 6.9 & 1.27 & 3.78 & 4.18 \\
\hline Margarine & 18.6 & 1.34 & 3.15 & 3.42 \\
\hline Sugar & 16.1 & 11.87 & 22.79 & 25.49 \\
\hline Chocolate & 87.2 & 9.85 & 21.22 & 24.07 \\
\hline $\begin{array}{l}\text { Soft drinks } \\
\text { (litres) }\end{array}$ & & 12.23 & 18.72 & 21.10 \\
\hline Coffee (b) & 3.0 & 36.56 & 69.66 & 78.26 \\
\hline & & $\mathbf{2 4 5 . 0 6}$ & $\mathbf{5 9 9 . 0 2}$ & 703.06 \\
\hline Total selected foods & & & & \\
\hline
\end{tabular}

Source: Estimated quantities of selected foods consumed in Sydney are derived from Australia, Department of Health, National dietary survey of adults: 1983, No. 1, Foods consumed, and Australia, Department of Health and Community Services, National dietary survey of school children (aged 10-15): 1985, Report 1, Foods consumed. Estimates represent the total annualised intake for a man aged 35-44 years, a woman aged 35-44 years, a girl aged 12 years and a boy aged 10 years. The prices of foods other than meat and fish are for October or November 1987 and are from International Labour Office, Bulletin of labour statistics, October inquiry results in 1987 and 1988, Geneva, 1989. Average prices for beef, pork, ham and bacon, chicken and fish in Sydney for the December quarter of 1984 are given in Australian Bureau of Agricultural and Resource Economics, Household meat consumption in Sydney and Melbourne, Canberra 1988. These were brought forward to the December quarter of 1987 using published ABS price index and price data. Prices for these items for Tokyo and Osaka are 1987 average unit prices of household consumption as given in Japan, Statistics Bureau, Annual Report on the Family Income and Expenditure Survey 1987. The cost of purchase in local currencies was calculated on the assumption that all of the assumed quantity consumed of each item was expended on the purchase of the particular product/specification (or most nearly comparable product/specification) priced in the October 1987 ILO Price Inquiry. The prices in local currencies were then converted into costs in hours worked using the estimates of average hourly earnings of all persons in Table 6 .

(a) 'Quantity consumed' includes the 'beef equivalent' of the quantity consumed of mutton and lamb, using the estimated average prices in the December quarter of 1987.

(b) Average consumption of coffee by a family of four is estimated from per capita consumption statistics in the United Nations Statistical Yearbook 1987. It is assumed that one-half of the coffee is purchased as instant coffee. 
Table 7B Average annual household purchases of selected foods in Tokyo and Osaka, and costs of purchase expressed in hours of work in Sydney, Tokyo and Osaka 1987

\begin{tabular}{|c|c|c|c|c|c|c|}
\hline & \multicolumn{2}{|c|}{ Quantity purchased } & \multicolumn{2}{|c|}{$\begin{array}{c}\text { Cost of quantity } \\
\text { purchased in Tokyo in: }\end{array}$} & \multicolumn{2}{|c|}{$\begin{array}{c}\text { Cost of quantity } \\
\text { purchased in Osaka in: }\end{array}$} \\
\hline & Tokyo & Osaka & Sydney & Tokyo & Sydney & Osaka \\
\hline & kg & kg & hours & hours & hours & hours \\
\hline \multicolumn{7}{|c|}{ Cereals } \\
\hline Bread & 40.2 & 44.8 & 5.93 & 9.84 & 6.60 & 13.38 \\
\hline Flour & 3.2 & 4.1 & 0.28 & 0.43 & 0.36 & 0.62 \\
\hline Pasta & 31.0 & 37.7 & 6.00 & 9.80 & 7.30 & 13.51 \\
\hline Rice & 122.2 & 142.5 & 12.16 & 38.94 & 14.17 & 53.11 \\
\hline Biscuits & 3.9 & 2.0 & 1.73 & 2.38 & 0.88 & 1.40 \\
\hline & & & 26.10 & 61.39 & 29.31 & 82.02 \\
\hline \multicolumn{7}{|c|}{ Meat and fish } \\
\hline Beef & 9.7 & 16.7 & 4.41 & 23.12 & 7.61 & 44.19 \\
\hline Pork & 19.5 & 13.3 & 7.90 & 18.26 & 5.37 & 16.66 \\
\hline $\begin{array}{l}\text { Ham and } \\
\text { bacon }\end{array}$ & 5.8 & 5.4 & 3.38 & 8.31 & 3.15 & 9.01 \\
\hline Chicken & 12.4 & 13.9 & 3.82 & 8.01 & 4.28 & 11.41 \\
\hline Sausages & 4.6 & 3.9 & 1.08 & 4.69 & 0.91 & 4.13 \\
\hline Fish & 52.6 & 56.8 & 33.96 & 66.42 & 36.67 & 83.70 \\
\hline & & & 54.55 & 128.81 & 57.99 & 169.10 \\
\hline \multicolumn{7}{|c|}{ Dairy products, eggs } \\
\hline Fresh milk & 108.1 & 103.0 & 7.97 & 14.23 & 7.59 & 17.62 \\
\hline Butter & 0.5 & 0.4 & 0.16 & 0.53 & 0.13 & 0.49 \\
\hline Cheese & 1.9 & 1.1 & 1.05 & 1.63 & 0.61 & 1.09 \\
\hline Icecream & 11.2 & 11.4 & 1.27 & 4.75 & 1.30 & 5.31 \\
\hline Eggs & 35.7 & 45.6 & 9.03 & 7.25 & 11.53 & 9.60 \\
\hline & & & 19.48 & 28.39 & 21.16 & 34.11 \\
\hline \multicolumn{7}{|c|}{ Fruit and vegetables } \\
\hline Oranges & 37.2 & 34.0 & 4.56 & 12.05 & 4.17 & 14.37 \\
\hline Lemons & 2.0 & 1.6 & 0.17 & 0.33 & 0.14 & 0.29 \\
\hline Apples & 15.2 & 15.9 & 3.16 & 4.40 & 3.30 & 5.62 \\
\hline Bananas & 14.1 & 12.2 & 1.52 & 2.13 & 1.31 & 2.08 \\
\hline $\begin{array}{l}\text { Canned } \\
\text { fruit }\end{array}$ & 1.7 & 1.9 & 0.31 & 0.71 & 0.27 & 0.81 \\
\hline Potatoes & 17.5 & 21.0 & 1.12 & 2.65 & 1.34 & 3.91 \\
\hline Onions & 18.9 & 21.9 & 1.68 & 1.79 & 1.94 & 2.37 \\
\hline Carrots & 11.5 & 8.9 & 1.16 & 2.78 & 0.90 & 2.45 \\
\hline Tomatoes & 19.2 & 12.4 & 3.33 & 6.33 & 2.15 & 5.88 \\
\hline
\end{tabular}




\begin{tabular}{|c|c|c|c|c|c|c|}
\hline & \multicolumn{2}{|c|}{ Quantity purchased } & \multicolumn{2}{|c|}{\begin{tabular}{|c|} 
Cost of quantity \\
purchased in Tokyo in:
\end{tabular}} & \multicolumn{2}{|c|}{$\begin{array}{c}\text { Cost of quantity } \\
\text { purchased in Osaka in }\end{array}$} \\
\hline & Tokyo & Osaka & \multirow{2}{*}{$\begin{array}{c}\text { Sydney } \\
\text { hours }\end{array}$} & \multirow{2}{*}{$\begin{array}{l}\text { Tokyo } \\
\text { hours }\end{array}$} & \multirow{2}{*}{$\begin{array}{c}\text { Sydney } \\
\text { hours }\end{array}$} & \multirow{2}{*}{$\begin{array}{l}\text { Osaka } \\
\text { hours }\end{array}$} \\
\hline & kg & kg & & & & \\
\hline $\begin{array}{l}\text { Chinese } \\
\text { Cabbage }\end{array}$ & 12.5 & 16.4 & 1.94 & 1.61 & 2.55 & 2.24 \\
\hline \begin{tabular}{|l} 
Green \\
Peppers
\end{tabular} & 3.3 & 2.7 & 1.35 & 1.30 & 1.11 & 1.17 \\
\hline Eggplants & 9.6 & 9.1 & 4.25 & 2.99 & 4.03 & 3.43 \\
\hline \begin{tabular}{|l|} 
Sweet \\
Potatoes
\end{tabular} & 6.1 & 5.2 & 1.58 & 1.59 & 1.34 & 1.84 \\
\hline & & & 27.24 & 43.98 & 25.68 & 50.44 \\
\hline \multicolumn{7}{|c|}{ Other foods } \\
\hline Margarine & 2.7 & 2.8 & 0.50 & 1.48 & 0.52 & 1.70 \\
\hline Sugar & 8.0 & 9.5 & 0.58 & 1.35 & 0.68 & 1.75 \\
\hline Coffee & 1.6 & 1.6 & 3.04 & 4.64 & 3.26 & 5.62 \\
\hline & & & 4.12 & 7.47 & 4.46 & 9.07 \\
\hline \multicolumn{3}{|c|}{\begin{tabular}{|l} 
Total, selected foods \\
\end{tabular}} & 131.49 & 270.04 & 138.60 & 344.74 \\
\hline
\end{tabular}

Source: Average annual household purchases of the selected foods in Tokyo and Osaka are from Japan, Statistics Bureau, Annual Report on the Family Income and Expenditure Survey 1987. The quantities purchased of biscuits, icecream and canned fruit are inferred from average annual family expenditure and the prices in the ILO October 1987 inquiry. For the sources used for prices and the method of calculation of costs in hours worked see the source to Table 7A.

Table 7 is in two parts, Table 7A shows the cost in hours of work in the three cities of a basket of foodstuffs which is representative of the Australian pattern of consumption of the foods concerned (expenditure on which accounts for more than one-half of household food expenditure in Sydney), whilst Table 7B gives corresponding details for baskets of food representative of the Tokyo and Osaka patterns of consumption of the items listed. ${ }^{12}$ Both parts of the table show that the number of hours which must be worked in order to earn household food supplies is far greater in Tokyo and Osaka than in Sydney.

The food regimen shown in Table 7A, which is representative of annual consumption of the foods concerned by a four-person family in Sydney, could have been purchased for 245 hours work by the average employee in Sydney in 1987. The cost would have been about 600 hours of work in Tokyo, and 700 hours in Osaka.

12 The estimates of quantities in Tables 7A and 7B should not be compared as they are on differing bases. Those in Table 7A are estimates of the quantities of food consumed by a family of two adults and two children, whilst those in Table 7B are reported average amounts of foods purchased (other than at restaurants, etc) by all households of two or more persons. 
As would be expected, the relative differences are somewhat less marked if the comparison is based on consumption patterns in the Japanese cities. However, the costs in hours worked of baskets of goods representative of consumption patterns in Tokyo and Osaka were still far greater in those cities than in Sydney - by a margin of over 2 to 1 in the case of Tokyo and of about 2.5 to 1 in the case of Osaka.

Similar information in relation to purchases of electricity is shown in Table 8. The table shows, for the average usage of electricity by several household types, the cost in hours worked in Sydney, Tokyo and Osaka of purchasing supplies at the general household tariff. Again the costs in hours worked in the Japanese cities were more than twice as great, and in some cases more than three times as great, as in Sydney.

Table 8 Average annual consumption of electricity by households in Sydney by household composition and costs of purchase expressed in hours of work in Sydney, Tokyo and Osaka 1987

\begin{tabular}{|c|c|c|c|c|}
\hline & \multirow{2}{*}{$\begin{array}{l}\text { Average } \\
\text { consumption in } \\
\text { Sydney }\end{array}$} & \multicolumn{3}{|c|}{ Cost of purchase in hours of work } \\
\hline & & \multirow[t]{2}{*}{$\begin{array}{c}\text { Sydney } \\
\text { hours }\end{array}$} & \multirow[t]{2}{*}{$\begin{array}{l}\text { Tokyo } \\
\text { hours }\end{array}$} & \multirow[t]{2}{*}{$\begin{array}{l}\text { Osaka } \\
\text { hours }\end{array}$} \\
\hline & kwh & & & \\
\hline Single person & 3,500 & 25.0 & 57.5 & 64.7 \\
\hline $\begin{array}{l}\text { Two adults, no } \\
\text { children }\end{array}$ & 5,830 & 40.3 & 105.7 & 120.3 \\
\hline $\begin{array}{l}\text { Two adults, one or } \\
\text { two children }\end{array}$ & 8,592 & 58.4 & 162.9 & 186.2 \\
\hline $\begin{array}{l}\text { Two adults, three or } \\
\text { four children }\end{array}$ & 9,924 & 67.1 & 190.4 & 218.0 \\
\hline
\end{tabular}

Source: The average annual consumption of electricity in Sydney by households of the specified types is from Australian Bureau of Statistics, New South Wales Energy Survey, October 1984: Part 2, Household Energy Consumption (ABS Catalogue No. 8212.1). The tariffs assumed for the purpose of estimating costs are: Sydney, from January 1, 1987, 10.21 cents for first $800 \mathrm{kwh}$ per annum, 7.309 cents for the remainder; Tokyo, at end 1986, 3120 yen per annum standing charge, 18.98 yen per kwh for first 1440 kwh per annum, 26.23 yen per kwh for next $1560 \mathrm{kwh}$ per annum, 31.28 yen per kwh for the remainder; Osaka at end 1986, 17.33 yen per kwh for first $180 \mathrm{kwh}$ per annum, 20.06 yen per kwh for next $1260 \mathrm{kwh}$ per annum, 27.06 yen per kwh for next $1560 \mathrm{kwh}$ per annum, 31.96 yen per kwh for the remainder. For the method of calculation of costs in hours worked, see Table 7B.

The costs in hours worked of most other goods and services purchased by households would also have been higher in the Japanese cities than in Sydney, but by a considerably narrower margin. This can be inferred from Table 9, which presents OECD estimates for Australia and Japan of the price levels of major components of consumption expenditure in relation to the prices of foods in 1985. 
Measuring and Promoting Wellbeing: How Important is Economic Growth?

Table 9 Australia and Japan: prices of selected components of household consumption expenditure in relation to prices of food 1985

\begin{tabular}{|l|c|c|}
\hline & Australia & Japan \\
\hline Food & 100 & 100 \\
\hline Clothing & 134 & 80 \\
\hline Household equipment and operation & 127 & 83 \\
\hline Transport and communications & 123 & 87 \\
\hline Education, recreation and culture & 126 & 82 \\
\hline Miscellaneous goods and services & 133 & 85 \\
\hline
\end{tabular}

Source: The table is derived from OECD, Purchasing Power Parities and Real Expenditures 1985, Table 12, which shows the relative price levels of each component of final expenditure on GDP in relation to GDP as a whole, at average OECD prices.

The OECD estimates are based on prices of many hundreds of individual goods and services supplied by statistical offices in individual member countries. They imply that, taking the structure of relative prices in the OECD area as a whole as the reference base, average prices of a wide range of consumer goods and services were dearer in Australia and cheaper in Japan in relation to the average prices of food. The margins of difference were, however, much smaller than the differences in the costs of food in terms of hours worked shown in Table 7. The estimates are therefore consistent with the proposition that the 'hours of work' costs of these other objects of consumption were on average lower in absolute terms in Sydney than in the Japanese cities.

In short, the available evidence indicates that the purchasing power of earnings, as measured by the command over goods and services obtained on average by a given amount of working time, is much greater in Sydney than in the Japanese cities. The margin of advantage in favour of Sydney workers is greater for women than for men, and greater for the 'necessities of life' than for other objects of consumption.

\section{Living standards of low and high income households}

The comments about relative living standards which were quoted at the beginning of this paper refer to the per capita income of 'Japan' being the world's highest and to the ranking of 'Australia' in terms of living standards. In fact, of course, it is not countries but people who have high or low incomes or living standards. National accounts-based comparisons of relative real incomes place the emphasis on averages of aggregates, and may not say very much about the experience of individuals, families or households. 
This section looks at some measures of the standard or level of living of low and high income households in Sydney and in the four Japanese prefectures in 1984. The details are provided in Table 10, which is in three parts. Table 10A compares the composition of income and expenditure and certain other characteristics of all households of two or more persons in Sydney and each of the prefectures, whilst Tables 10B and 10C provide the same information for households of two or more persons in the lowest and highest income quintile in each region. 'Income quintile groups' are 20 per cent groupings of the population when households (in this case, households of two or more persons) are ranked in ascending order according to each household's total gross weekly income.

Table 10A Sydney and four Japanese prefectures: income, expenditure and selected characteristics of all households (a) 1984

\begin{tabular}{|c|c|c|c|c|c|}
\hline & Sydney & Tokyo & Kanagawa & Kyoto & Osaka \\
\hline $\begin{array}{l}\text { Persons per household } \\
\text { (number) }\end{array}$ & 3.26 & 3.56 & 3.76 & 3.77 & 3.70 \\
\hline \multicolumn{6}{|c|}{ Composition of income (\%) } \\
\hline Wages \& salaries & 76.1 & 70.4 & 77.3 & 68.6 & 72.9 \\
\hline Own business & 7.8 & 16.2 & 10.9 & 18.7 & 14.8 \\
\hline Pensions/benefits (b) & 8.9 & 4.3 & 4.3 & 6.6 & 4.8 \\
\hline Other income (b) & 7.2 & 9.2 & 7.6 & 6.1 & 7.5 \\
\hline Total income & 100.0 & 100.0 & 100.0 & 100.0 & 100.0 \\
\hline \multicolumn{6}{|c|}{ Labour force work } \\
\hline $\begin{array}{l}\text { Earners per household } \\
\text { (number) }\end{array}$ & 1.5 & 1.5 & 1.5 & 1.5 & 1.5 \\
\hline $\begin{array}{l}\text { Earned income (c) as \% } \\
\text { of total income }\end{array}$ & 83.9 & 86.6 & 88.2 & 87.3 & 87.7 \\
\hline \multicolumn{6}{|c|}{ Housing tenure } \\
\hline Paying rent (\%) & 24.9 & 43.2 & 31.2 & 20.4 & 40.4 \\
\hline Rent as $\%$ of income (d) & 14.2 & 7.5 & 5.6 & 3.9 & 5.6 \\
\hline Owning dwelling (e) (\%) & 71.6 & 61.7 & 70.6 & 79.2 & 60.6 \\
\hline With mortgage (e) (\%) & 36.4 & 29.3 & 39.4 & 33.4 & 27.9 \\
\hline $\begin{array}{l}\text { Mortgage/income ratio } \\
\text { (f) }\end{array}$ & 0.69 & 1.56 & 1.34 & 1.29 & 1.52 \\
\hline \multicolumn{6}{|c|}{ Composition of expenditure (g) (\%) } \\
\hline Cereals & 1.5 & 4.9 & 5.1 & 5.1 & 5.7 \\
\hline Meat \& fish & 5.1 & 9.9 & 10.1 & 12.1 & 12.0 \\
\hline Fruit \& veges & 3.0 & 7.87 & 7.5 & 7.4 & 7.8 \\
\hline $\begin{array}{l}\text { Food (except eating } \\
\text { out) (h) }\end{array}$ & 18.0 & 32.3 & 32.4 & 34.3 & 35.3 \\
\hline $\begin{array}{l}\text { Power and water } \\
\text { charges }\end{array}$ & 4.0 & 8.5 & 8.1 & 8.2 & 8.4 \\
\hline Communications & 2.0 & 3.4 & 3.3 & 3.3 & 3.2 \\
\hline
\end{tabular}


Measuring and Promoting Wellbeing: How Important is Economic Growth?

\begin{tabular}{|l|c|c|c|c|c|}
\hline & Sydney & Tokyo & Kanagawa & Kyoto & Osaka \\
\hline Total food \& utilities & 24.0 & 44.1 & 43.8 & 45.8 & 47.0 \\
\hline Clothing & 9.3 & 10.1 & 9.8 & 10.1 & 9.4 \\
\hline Household operation & 14.3 & 7.8 & 8.5 & 8.6 & 7.4 \\
\hline Transportation & 19.2 & 8.8 & 10.6 & 8.3 & 8.3 \\
\hline Reading \& recreation & 14.2 & 12.6 & 12.6 & 11.5 & 11.7 \\
\hline Eating out & 7.5 & 7.4 & 6.0 & 6.1 & 6.5 \\
\hline Miscellaneous & 11.5 & 9.3 & 8.7 & 9.7 & 9.7 \\
\hline $\begin{array}{l}\text { Total other (non-food) } \\
\text { expenditure }\end{array}$ & 76.0 & 55.9 & 56.2 & 54.2 & 53.0 \\
\hline Total expenditure (g) & 100.0 & 100.0 & 100.0 & 100.0 & 100.0 \\
\hline
\end{tabular}

Table 10B Sydney and four Japanese prefectures: income, expenditure and selected characteristics of households (a) in lowest income quintile group 1984

\begin{tabular}{|c|c|c|c|c|c|}
\hline & Sydney & Tokyo & Kanagawa & Kyoto & Osaka \\
\hline $\begin{array}{l}\text { Persons per household } \\
\text { (number) }\end{array}$ & 2.59 & 3.00 & 3.21 & 2.97 & 3.00 \\
\hline \multicolumn{6}{|c|}{ Composition of income (\%) } \\
\hline Wages \& salaries & 4.9 & 52.3 & 65.6 & 40.9 & 52.8 \\
\hline Own business & 6.9 & 21.6 & 13.8 & 27.4 & 21.0 \\
\hline Pensions/benefits (b) & 74.2 & 15.6 & 13.2 & 22.7 & 16.9 \\
\hline Other income (b) & 14.0 & 10.5 & 4.8 & 9.0 & 9.3 \\
\hline Total income & 100.0 & 100.0 & 100.0 & 100.0 & 100.0 \\
\hline \multicolumn{6}{|c|}{ Labour force work } \\
\hline Earners per household (no.) & 0.2 & 1.3 & 1.2 & 1.1 & 1.1 \\
\hline $\begin{array}{l}\text { Earned income (c) as \% of } \\
\text { total income }\end{array}$ & 11.8 & 73.9 & 79.4 & 68.3 & 73.8 \\
\hline \multicolumn{6}{|c|}{ Housing tenure } \\
\hline Paying rent (\%) & 36.9 & 57.6 & 52.2 & 38.9 & 58.3 \\
\hline Rent as \% of income (d) & 35.4 & 16.3 & 12.2 & 8.2 & 11.5 \\
\hline Own dwelling (e) (\%) & 59.8 & 47.7 & 47.8 & 61.2 & 42.2 \\
\hline With mortgage (e) (\%) & 9.0 & 8.0 & 14.3 & 9.5 & 9.2 \\
\hline Mortgage/income ratio (f) & 1.39 & 2.81 & 2.40 & 2.04 & 2.34 \\
\hline \multicolumn{6}{|c|}{ Composition of expenditure (g) (\%) } \\
\hline Cereals & 2.3 & 6.3 & 6.1 & 6.4 & 7.0 \\
\hline Meat \& fish & 7.0 & 10.4 & 10.6 & 12.8 & 12.8 \\
\hline Fruit \& veges & 4.8 & 9.0 & 8.4 & 9.1 & 9.2 \\
\hline Total food (exc. eating out) (h) & 24.8 & 36.9 & 36.2 & 38.8 & 40.0 \\
\hline Power \& water charges & 5.2 & 9.8 & 9.2 & 9.7 & 10.1 \\
\hline Communications & 2.4 & 3.9 & 3.7 & 4.0 & 3.8 \\
\hline Food \& utilities & 32.4 & 50.7 & 49.2 & 52.4 & 53.9 \\
\hline Clothing & 8.1 & 7.5 & 7.5 & 6.4 & 6.8 \\
\hline Household operation & 14.0 & 7.6 & 8.7 & 8.7 & 7.5 \\
\hline
\end{tabular}




\begin{tabular}{|l|c|c|c|c|c|}
\hline & Sydney & Tokyo & Kanagawa & Kyoto & Osaka \\
\hline Transportation & 18.2 & 7.4 & 8.0 & 7.9 & 7.1 \\
\hline Reading \& recreation & 11.4 & 10.5 & 10.9 & 10.2 & 9.3 \\
\hline Eating out & 4.4 & 6.2 & 5.9 & 4.9 & 5.8 \\
\hline Miscellaneous & 11.5 & 10.1 & 9.8 & 9.5 & 9.7 \\
\hline $\begin{array}{l}\text { Total other (non-food) } \\
\text { expenditure }\end{array}$ & 67.6 & 49.3 & 50.8 & 47.6 & 46.2 \\
\hline Total expenditure (g) & 100.0 & 100.0 & 100.0 & 100.0 & 100.0 \\
\hline
\end{tabular}

Table 10C Sydney and four Japanese prefectures: income, expenditure and selected characteristics of households (a) in highest income quintile group 1984

\begin{tabular}{|c|c|c|c|c|c|}
\hline & Sydney & Tokyo & Kanagawa & Kyoto & Osaka \\
\hline $\begin{array}{l}\text { Persons per household } \\
\text { (number) }\end{array}$ & 3.79 & 4.0 & 4.19 & 4.23 & 4.06 \\
\hline \multicolumn{6}{|c|}{ Composition of income (\%) } \\
\hline Wages \& salaries & 80.5 & 70.8 & 73.3 & 69.0 & 72.5 \\
\hline Own business & 10.4 & 12.9 & 13.2 & 19.4 & 13.1 \\
\hline Pensions/benefits (b) & 1.9 & 2.6 & 3.0 & 3.9 & 4.0 \\
\hline Other income (b) & 7.1 & 13.7 & 10.5 & 7.7 & 10.4 \\
\hline Total income & 100.0 & 100.0 & 100.0 & 100.0 & 100.0 \\
\hline \multicolumn{6}{|c|}{ Labour force work } \\
\hline Earners per household (no.) & 2.5 & 1.8 & 2.0 & 1.9 & 1.8 \\
\hline $\begin{array}{l}\text { Earned income (c) as \% of } \\
\text { total income }\end{array}$ & 90.9 & 83.7 & 86.5 & 88.4 & 85.6 \\
\hline \multicolumn{6}{|c|}{ Housing tenure } \\
\hline Paying rent $(\%)$ & 15.3 & 26.6 & 9.9 & 5.6 & 16.0 \\
\hline Rent as \% of income (d) & 10.8 & 3.6 & 3.5 & 1.6 & 3.2 \\
\hline Owning dwelling (e) (\%) & 83.0 & 83.5 & 94.6 & 93.4 & 85.8 \\
\hline With mortgage (e) (\%) & 49.8 & 51.4 & 59.1 & 52.8 & 45.3 \\
\hline Mortgage/income ratio (f) & 0.38 & 0.97 & 0.77 & 0.87 & 0.93 \\
\hline \multicolumn{6}{|c|}{ Composition of expenditure (g) (\%) } \\
\hline Cereals & 1.1 & 3.9 & 4.1 & 4.0 & 4.4 \\
\hline Meat \& fish & 3.8 & 9.6 & 9.2 & 10.8 & 11.0 \\
\hline Fruit \& veges & 2.4 & 6.9 & 6.4 & 6.2 & 6.9 \\
\hline $\begin{array}{l}\text { Total food (exc. eating out) } \\
\text { (h) }\end{array}$ & 14.3 & 28.1 & 27.3 & 28.8 & 30.0 \\
\hline Power \& water charges & 3.2 & 7.5 & 7.5 & 6.7 & 7.1 \\
\hline Communications & 1.6 & 3.2 & 3.2 & 3.0 & 3.0 \\
\hline Food \& utilities & $19.1^{\vee}$ & 38.8 & 38.0 & 38.5 & 40.1 \\
\hline Clothing & 10.4 & 12.2 & 12.8 & 14.2 & 11.9 \\
\hline Household operation & 15.4 & 9.2 & 9.1 & 9.7 & 7.8 \\
\hline Transportation & 19.1 & 9.4 & 11.7 & 8.0 & 9.2 \\
\hline Reading \& recreation & 15.7 & 13.4 & 14.1 & 11.7 & 13.2 \\
\hline Eating out & 9.5 & 7.4 & 5.6 & 6.8 & 6.6 \\
\hline Miscellaneous & 10.9 & 9.6 & 8.6 & 11.1 & 11.2 \\
\hline $\begin{array}{l}\text { Total other (non-food) } \\
\text { expenditure }\end{array}$ & 81.0 & 61.2 & 61.9 & 61.5 & 59.9 \\
\hline Total expenditure $(\mathrm{g})$ & 100.0 & 100.0 & 100.0 & 100.0 & 100.0 \\
\hline
\end{tabular}


The first line of each part of the table shows that the average household size in Sydney was significantly smaller than in the Japanese prefectures. This was particularly true of households in the lowest income quintile group. The main reason for this was that, in Sydney, couples without children are much more likely to live as a separate household.

The next sections of each part of the table show the composition of income and the numbers of earners per household. In these respects, there were marked differences between Sydney and the Japanese prefectures in the lowest income quintile group. The incomes of low-income households in Sydney were derived mainly from social security pensions and benefits, whereas in the Japanese prefectures the incomes of this group were derived predominantly from employment. Reflecting this difference, the average number of earners per household in Sydney households in the lowest income quintile group was only 0.2 , compared with an average of more than one earner per household in this group in the Japanese prefectures.

The section on housing tenure shows that, in all cities, the proportion of households paying rent was much higher in the lowest income quintile group. The difference in this respect was much greater in the Japanese prefectures than in Sydney.

The next section shows the composition of expenditure as revealed by household expenditure surveys conducted in Australia and Japan in 1984. Expenditure on housing, education and health are excluded from the table on the grounds that spending by individual households on these items do not necessarily reflect their relative consumption of the services concerned. Expenditure on other items is divided into two categories of goods and services according to whether demand is inelastic or elastic in relation to income. In the first, 'inelastic' group are 'food and utilities', which includes food (excluding eating out), power and water charges and communications (largely telephone charges). The second 'elastic' group includes clothing, household services and operation, transportation, reading and recreation, eating out, alcohol, tobacco, personal care and other miscellaneous items.

Although, as noted above, the income of low-income households in Sydney is derived mainly from government social security benefits, only 32 per cent of the selected expenditures of the Sydney households in this group was devoted to food and utilities. The corresponding proportion in the Japanese households, whose incomes came mainly from earnings from employment, ranged from 49 per cent in Kanagawa to 54 per cent in Osaka. Even in the highest income quintile group, the proportion of the selected expenditures directed to food and utilities in the Japanese prefectures approached 40 per cent - a far higher proportion than in the lowest income quintile group in Sydney. 
The table also reveals significant differences in the allocation of expenditures within the food group and, in particular, to the relationship of spending on meat and fish to spending on cereals. Higher income groups spent relatively more on meat and fish in all of the cities, but the absolute ratios were lower in Japan. In Tokyo, for example, the ratio of expenditure on meat and fish to expenditure on cereals rose from 1.66 in the lowest income quintile group to 2.45 in the highest; whereas in Sydney the corresponding ratio rose from 3.01 in the lowest group to 3.35 in the highest income quintile group.

Whilst there are substantial differences between income groups in all cities, the statistics in Table 10 suggest that, on average, households in Sydney are more affluent than their Japanese counterparts. In particular, they suggest that Sydney households have more scope for discretionary expenditures.

\section{Comparisons of housing conditions}

The comparisons in Table 1 showed that Sydney's population density is far lower than that of the big Japanese cities. This difference is reflected in housing conditions in a number of ways.

Although the majority of Japanese families share the preference of most Australian families for a separate house on its own allotment, most people in the larger Japanese cities live in apartments in multi-unit structures. The proportion of dwellings in Sydney and the Japanese prefectures which were in structures of various types is shown for 1988 in Table 11. The table shows that the proportion of dwellings which were detached houses (including semi-detached houses) ${ }^{13}$ was 74 per cent in Sydney, compared with only 35 per cent in Tokyo and 38 per cent in Osaka. Conversely, the proportion of dwellings in structures of more than three stories was only three per cent in Sydney, compared with almost 30 per cent in Tokyo and Osaka.

13 In the Housing Survey of Japan a detached house is defined as 'A building which consists of a dwelling unit'. 
Table 11 Sydney and four Japanese prefectures: occupied private dwellings by type of structure

\begin{tabular}{|l|c|c|c|c|c|}
\hline & $\begin{array}{c}\text { Sydney } \\
(\text { ‘000) }\end{array}$ & $\begin{array}{c}\text { Tokyo } \\
(\text { ‘000) }\end{array}$ & $\begin{array}{c}\text { Kanagawa } \\
(\text { ‘000) }\end{array}$ & $\begin{array}{c}\text { Kyoto } \\
(\text { '000) }\end{array}$ & $\begin{array}{c}\text { Osaka } \\
\text { ('000) }\end{array}$ \\
\hline Number of dwellings & $1,110.1$ & $4,266.2$ & $2,444.1$ & 833.3 & $2,860.9$ \\
\hline \multicolumn{7}{|c|}{ Percentage of total } \\
\hline Detached house (a) & 74.4 & 34.8 & 50.3 & 57.8 & 37.6 \\
\hline Medium density (b) & 22.4 & 35.5 & 29.4 & 24.6 & 33.1 \\
\hline Flats over 3 stories (c) & 3.2 & 29.7 & 20.3 & 17.6 & 29.3 \\
\hline & 100.0 & 100.0 & 100.0 & 100.0 & 100.0 \\
\hline
\end{tabular}

Source: The statistics of Sydney are from the ABS 1988 Housing Survey, and those for the Japanese prefectures are from the Housing Survey 1988. The numbers of dwellings exclude other types of structure.

(a) For Sydney, comprises 'separate house' and 'semi-detached house'.

(b) For Sydney, comprises 'medium density' and 'low rise flat/unit'. For Japanese prefectures, comprises 'tenement houses' and 'apartments' in structures of 1, 2 or 3 stories. The numbers of apartments of 3 stories are estimated by assuming that the proportion of apartments in structures of 3 stories to apartments in structures of 3-5 stories is the same in Tokyo and Kanagawa as in Keihin Major Metropolitan Area, and the proportion in Kyoto and Osaka is the same as in Keihanshin Major or Metropolitan Area.

(c) For Japanese prefectures, apartments in structures of 4-5 stories are estimated by the method described in footnote (b).

Moreover, the minority of dwellings in the large Japanese cities which are detached houses are, for the most part, built on much smaller allotments than houses in Sydney. Table 12 provides indicative figures suggesting that average allotments in Sydney could be as much as four times as large as in the Japanese prefectures. 
Table 12 Sydney and four Japanese prefectures: residential land areas and prices 1988

\begin{tabular}{|c|c|c|c|}
\hline & \multirow[t]{2}{*}{$\begin{array}{l}\text { Allotment size } \\
\text { square metre }\end{array}$} & \multicolumn{2}{|c|}{$\begin{array}{c}\text { Land prices (hours of } \\
\text { work) }\end{array}$} \\
\hline & & per allotment & $\begin{array}{c}\text { per square } \\
\text { metre }\end{array}$ \\
\hline Sydney & 591 & 14,750 & 25.0 \\
\hline \multicolumn{4}{|l|}{ Groups of suburbs } \\
\hline With smallest allotments (a) & 142 & 9,040 & 63.5 \\
\hline Other inner $(0-6 \mathrm{~km})$ & 452 & 24,550 & 54.3 \\
\hline Middle distance $(6-25 \mathrm{~km})$ & 636 & 12,060 & 23.6 \\
\hline Outer (over $25 \mathrm{kms}$ ) & 671 & 6,830 & 12.2 \\
\hline Gosford/Wyong & 738 & 4,980 & 6.7 \\
\hline Tokyo & 151 & 87,630 & 580.3 \\
\hline Kanagawa & 184 & 39,570 & 215.0 \\
\hline Kyoto & 163 & 19,200 & 117.8 \\
\hline Osaka & 129 & 23,950 & 185.7 \\
\hline
\end{tabular}

Source: For Sydney, allotment sizes for each group of suburbs and land prices per square metre in $\mathrm{A} \$$ were derived as simple averages from the dimensions of representative residential cottage sites and the values of standard serviced allotments as given in New South Wales, Valuer-General's Department, Real Estate Market 1989. The number of suburbs in the five groups shown are, respectively, 5, 6, 25, 19 and 3. Estimates for Sydney were derived as simple averages of the 58 suburbs. For the Japanese prefectures, the allotment sizes are the 'building area per dwelling' for detached houses from the 1988 Housing Survey, as given in Social indicators by prefecture 1989, page 124. Land prices per square metre in yen are as given in 'Average prices for land transactions: residential quarter' on page 387 of the same publication and land prices per allotment in yen are derived by multiplying the average price per square metre by the 'building area per dwelling'. Land prices in A\$ and yen were converted to 'hours of work' using average hourly earnings estimates for 1988 derived from Table 7.

(a) Balmain, Erskineville, Paddington, Redfern and Ultimo.

In the Japanese prefectures, the average allotment size on which separate houses were built ranged from 129 square metres in Osaka to 184 square metres in Kanagawa. The median size of allotments was even smaller, ranging from about 80 square metres in Osaka to about 140 square metres in Kanagawa.

These figures may be compared with the findings of a governmental study in New South Wales in the late $1970 \mathrm{~s}^{14}$ which was directed towards ensuring that required allotments in new developments were not bigger than people required or could afford. The study estimated that the space requirements for the average household's activities included 150 square metres for the home itself, 40 square metres for a carport for two cars, 100 square metres for an outdoor living area, 75 square metres for the front garden, 25 square metres for a vegetable garden and 25 square metres for an outdoor clothes drying area.

14 Quoted in New South Wales, Department of Environment and Planning, Technical Bulletin 15, Residential Development Standards 1982: 10. 
Table 12 also provides some indication of relative values of residential land in Sydney and the four prefectures. Comparisons should be made with caution for several reasons, including the big difference in allotment sizes. The figures in the table nonetheless suggest that, in a group of inner Sydney suburbs with allotments as small as those in the Japanese cities, the price per allotment in terms of hours of work in 1988 varied from almost one-half (Kyoto) to little more than one-tenth (Tokyo) of allotments in the Japanese prefectures.

Reference has been made to a study in the late 1970s which estimated that the space required for the average household's activities included 150 square metres for the dwelling alone. By the late 1980s the average floor area of new houses being constructed in Sydney was substantially larger than this. Table 13 shows that the average floor space for all new dwellings (including apartments, townhouses etc) commenced in New South Wales ${ }^{15}$ during the years 1984 to 1987 was more than twice as great as in Tokyo and almost twice as great as in the other three prefectures.

As well as being far larger, dwellings in Sydney are better equipped. Statistical information on bathroom and toilet facilities in dwellings in Sydney and the Japanese prefectures is presented in Table 14. In 1987, almost 99 per cent of dwellings in Sydney were equipped with one or more toilets and one or more showers. ${ }^{16}$ The corresponding proportions in Japanese cities were much lower. The 1988 Housing Survey in Japan also revealed that between nine per cent (Kyoto) and 20 per cent (Kanagawa) of dwellings had two or more flush toilets for the exclusive use of the household. In Sydney, where the average household size is significantly smaller, the proportion of dwellings with two or more toilets was 40 per cent.

15 The majority of the commencements were in Sydney and the average floor area of dwellings commenced in Sydney would not have been significantly less than for the state as a whole. 
Table 13 NSW and four Japanese Prefectures: average floor area of new dwellings constructed 1984-87

\begin{tabular}{|l|c|c|c|c|c|}
\hline & $\begin{array}{c}\text { NSW } \\
\text { (sq.m.) }\end{array}$ & $\begin{array}{c}\text { Tokyo } \\
\text { (sq.m.) }\end{array}$ & $\begin{array}{c}\text { Kanagawa } \\
\text { (sq.m.) }\end{array}$ & $\begin{array}{c}\text { Kyoto } \\
\text { (sq.m.) }\end{array}$ & $\begin{array}{c}\text { Other } \\
\text { (sq.m.) }\end{array}$ \\
\hline 1984 & 129.8 & 68.5 & 84.5 & 80.4 & 79.2 \\
\hline 1985 & 139.8 & 67.7 & 80.2 & 80.9 & 79.1 \\
\hline 1986 & 141.8 & 64.3 & 74.3 & 75.2 & 79.1 \\
\hline 1987 & 146.2 & 66.7 & 74.9 & 77.7 & 75.9 \\
\hline Total 1984-87 & $\mathbf{1 3 8 . 9}$ & $\mathbf{6 6 . 6}$ & $\mathbf{7 7 . 8}$ & $\mathbf{7 8 . 4}$ & $\mathbf{7 8 . 1}$ \\
\hline
\end{tabular}

Source: Statistics for New South Wales are unpublised results from the ABS Building Activity Survey. Those for the Japanese prefectures are from Statistics Bureau, Social Indicators by Prefecture 1989 and previous issues.

Table 14 Sydney (1987) and four Japanese prefectures (1988): bathroom and toilet facilities in private dwellings

\begin{tabular}{|l|c|c|c|c|c|}
\hline $\begin{array}{l}\text { Percentage of } \\
\text { dwellings with: }\end{array}$ & $\begin{array}{c}\text { Sydney } \\
\%\end{array}$ & Tokyo \% & $\begin{array}{c}\text { Kanagawa } \\
\%\end{array}$ & Kyoto \% & $\begin{array}{c}\text { Osaka } \\
\%\end{array}$ \\
\hline No flush toilet & 1.2 & 4.8 & 9.6 & 28.7 & 16.9 \\
\hline Flush toilet used jointly & - & 5 & 1.4 & 3.9 & 3.2 \\
\cline { 2 - 6 } & $\mathbf{1 . 2}$ & $\mathbf{9 . 8}$ & $\mathbf{1 1}$ & $\mathbf{3 2 . 6}$ & $\mathbf{2 0 . 1}$ \\
\hline $\begin{array}{l}\text { Flush toilets for exclusive } \\
\text { use of household } \\
\begin{array}{c}\text { At least 1 } \\
\text { At least 2 } \\
\text { At least 3 }\end{array}\end{array}$ & 98.8 & 90.2 & 89 & 67.4 & 79.9 \\
\cline { 2 - 7 } & 40.2 & 16.6 & 20.4 & 9 & 9.6 \\
\cline { 2 - 7 } No bathroom & 16.9 & n.a. & n.a. & n.a. & n.a. \\
\hline No shower & n.a. & 16.7 & 7.6 & 12.6 & 17.4 \\
\hline No bathtub & 1.2 & n.a. & n.a. & n.a. & n.a. \\
\hline
\end{tabular}

Source: The statistics for Sydney are from a survey conducted by the ABS in July 1987, the results of which were published in Domestic Water Use, New South Wales (ABS Calatogue No.8719). The data for the Japanese prefectures are from the 1988 Housing Survey of Japan: Volume 3: Results for Prefectures.

More information on household facilities is provided in Table 15. This table shows, for Sydney and the four selected Japanese prefectures, the proportion of all households possessing motor vehicles and various household durable goods. For most items the ownership rate was higher, and for several items far higher, in Sydney. ${ }^{17}$

17 Microwave ovens were an exception, but the ownership rate in Sydney was rising steeply at the time of the survey (1984). In a survey conducted in 1985-86, almost 40 per cent of Australian households possessing a microwave oven had acquired it during the preceding 12 months. 
Table 15 Sydney and four Japanese prefectures: possession of motor vehicles and household durable goods (\% of all households)

\begin{tabular}{|c|c|c|c|c|c|}
\hline & $\begin{array}{c}\text { Sydney } \\
\%\end{array}$ & Tokyo \% & $\begin{array}{c}\text { Kanagawa } \\
\%\end{array}$ & Kyoto \% & $\begin{array}{c}\text { Osaka } \\
\%\end{array}$ \\
\hline \multicolumn{6}{|l|}{ Motor vehicles } \\
\hline \multirow{3}{*}{$\begin{array}{l}\text { At least } 1 \\
\text { At least } 2 \\
\text { At least } 3\end{array}$} & 90 & 47.4 & 60.8 & 63.5 & 51.3 \\
\hline & 45.4 & 3.8 & 5.7 & 7.9 & 3.9 \\
\hline & 10.7 & 0.5 & 0.8 & 0.8 & 0.4 \\
\hline \multicolumn{6}{|l|}{\begin{tabular}{|l} 
Refrigerators \\
\end{tabular}} \\
\hline \multirow{2}{*}{$\begin{array}{l}\text { At least } 1 \\
\text { At least } 2\end{array}$} & 99.5 & 92.8 & 93.6 & 95.2 & 94.4 \\
\hline & 21.6 & 4.5 & 5.5 & 8.1 & 5.3 \\
\hline \multicolumn{6}{|l|}{ Washing machines } \\
\hline \multirow{2}{*}{$\begin{array}{l}\text { All } \\
\text { Fully automatic }\end{array}$} & 89.1 & 88.6 & 90.6 & 92.9 & 92.3 \\
\hline & 72.4 & 24.9 & 22.8 & 27.4 & 24 \\
\hline Clothes dryer & 52.5 & 9.5 & 6.4 & 7.2 & 8.8 \\
\hline Microwave oven & 23 & 38.1 & 42.2 & 48.4 & 52 \\
\hline \multicolumn{6}{|l|}{ Other ovens } \\
\hline \multirow{2}{*}{$\begin{array}{l}\text { Electric } \\
\text { Gas }\end{array}$} & 74.2 & 41.2 & 42.9 & 54.5 & 48.4 \\
\hline & 24.8 & 38.1 & 23.8 & 37.9 & 36.4 \\
\hline Telephone & 91.2 & 85.4 & 88.6 & 91.3 & 88.9 \\
\hline
\end{tabular}

Source: Statistics for Sydney are from the 1986 Census for motor vehicles: interpolated from surveys of household telephone connections in 1983 and 1986 for telephones; and from ABS New South Wales Energy Survey, October 1984 (ABS Caalogue No.8212.1) for other items. Statistics for the Japanese prefectures are from Statistics Bureau, 1984 National Survey of Family Income and Expenditure. Estimates for 2 or more person households and 1-person households are published separately and have been combined. In the case of 1-person households, it was assumed that the proportion of households possessing each item in the four individual prefectures bore the same relationship to the proportion for Japan as a whole as the corresponding proportion in respect of households of 2 or more persons.

\section{Land use}

Although the available statistical information is limited, undoubtedly Sydney's lower population densities are reflected not only in more spacious housing but in more generous provision of a range of other amenities: wider and less congested roads, larger grounds for schools in relation to student populations, larger grounds for hospitals and nursing homes in relation to patient populations, and more public open spaces and sporting facilities in relation to the total population. 
Table 16 Sydney and four Japanese prefectures: public open space and facilities for sport 1982

\begin{tabular}{|c|c|c|c|c|c|}
\hline & Sydney & Tokyo & Kanagawa & Kyoto & Osaka \\
\hline \multicolumn{6}{|l|}{ TOTAL } \\
\hline \multicolumn{6}{|l|}{ Sites } \\
\hline \multirow{5}{*}{$\begin{array}{l}\text { Number } \\
\text { Area (hectares) } \\
\text { Playing fields: Number } \\
\text { Tennis courts: Number } \\
\text { Netball courts: Number }\end{array}$} & 6,238 & 3,026 & 2,732 & 1,154 & 2,544 \\
\hline & 13,086 & 2,572 & 1,530 & 678 & 2,650 \\
\hline & 1,580 & 568 & 162 & 104 & 162 \\
\hline & 843 & 178 & 105 & 85 & 112 \\
\hline & 1,573 & n.a. & n.a. & n.a. & n.a. \\
\hline \multicolumn{6}{|c|}{ PER MILLION OF POPULATION } \\
\hline \multicolumn{6}{|l|}{ Sites } \\
\hline Number & 2,041 & 260 & 389 & 454 & 299 \\
\hline Area (hectares) & 4,283 & 220 & 215 & 265 & 310 \\
\hline Playing fields: Number & 517 & 48 & 22 & 40 & 19 \\
\hline Tennis courts: Number & 276 & 15 & 14 & 33 & 13 \\
\hline Netball courts: Number & 515 & n.a. & n.a. & n.a. & n.a. \\
\hline
\end{tabular}

Source: Information for Sydney is from New South Wales, Department of Environment and Planning, Research Study 5, 1982 Open Space Survey: Open Space in the Sydney Region (1985). The survey covered municipalities with $93 \%$ of the population of the Sydney Statistical Division in 1981. Figures for the number and area of open space sites relate to sites of less than 50 hectares only. Information for the Japanese prefectures is from issues of Social Indicators by Prefecture, and relates to 1982 for sites and to 1985 for playing fields and tennis courts. For the Japanese prefectures, 'playing fields' are described in the English translation of the text as 'Grounds for exercise', and include exercise grounds with an area of 992 square metres or more.'

Statistical information on this last aspect is presented in Table 16, which compares the number and area of public open space sites and the numbers of playing fields and tennis courts in Sydney and in the four Japanese prefectures in the early 1980s.

The table shows that, in relation to population, Sydney had over four times as many public open space sites as Kyoto and nearly eight times as many as Tokyo. If allowance is made for the greater average size of the Sydney sites, the differences were even greater. Sydney also had a much greater absolute number of public playing fields and public tennis courts than the four Japanese prefectures combined. In relation to population, the number of these facilities in Sydney was 10 to 20 times greater than in the Japanese prefectures. 


\section{Conclusion}

Japan's rate of economic growth has been much faster than that of other OECD countries for several decades, and this has been reflected in a rapid improvement in the living standards of the Japanese people. The improvement has occurred both in the quantifiable indicators which are drawn together in national accounts aggregates and in the less tangible aspects which are summarised in the phrase 'quality of life'.

Australia's per capita growth rate has been much slower, and in the 1980s many commentators asserted that the incomes and living standards of Australians had been surpassed by the Japanese. The statistics presented in this paper do not support this view. Even on the conventional measures, Australians apparently continued to enjoy higher real consumption levels per capita, in respect of virtually every significant category of expenditure. This was true notwithstanding the facts that they worked fewer hours each week, took longer holidays and had shorter working lives.

This paper has argued that the measures commonly used in inter-country comparisons are in any case inadequate. Many aspects of the mode or level of living which most people would regard as important to their own perception of their living standards are omitted from the reckoning. In general, the effect of allowing for these factors would be to reinforce the conclusion that, at the beginning of the 1990s, most people in Australia continued to enjoy higher living standards than their counterparts in Japan.

If Japan maintains a higher rate of economic growth than Australia in the years ahead, the gap in living standards will continue to narrow. If only because of the differing physical characteristics of the two countries, however, it can be expected that it will become increasingly important to recognise that lifestyles in Japan and Australia are very different. There is little point in trying to encapsulate the differences in any single measure, or to establish criteria against which the living standards in either country could be assessed as superior.

In both countries, the task will be to use the skills and strengths of their peoples to improve opportunities for the enhancement of their wellbeing in the broadest sense. 